\title{
The Effect of Fossil Energy and Other Environmental Taxes on Profit Incentives for Change in an Open Economy:
}

\section{Evidence from the UK}

Allan Webster* and Sukanya Ayatakshi

Business School, Bournemouth University, 89 Holdenhurst Road, Dorset BH8 8EB, UK

Tel: 0044-1202968744; 01202961874

awebster@bournemouth.ac.uk

sayatakshi@bournemouth.ac.uk

Keywords: Energy Taxes; Environmental Taxes; Input-Output Analysis; Profit Inc 


\section{The Effect of Fossil Energy and Other Environmental Taxes on Profit Incentives for Change in an Open Economy: Evidence from the UK}

\section{INTRODUCTION}

This paper is in the tradition of those which use input-output techniques to analyse fossil energy and environmental taxes. We put forward the view that, for a country which is open to trade at given world prices and adopts national taxes, the key mechanism for bringing about change in the short term is not through prices and, ultimately, consumer decisions but through profits and producer decisions. This mechanism provides incentives for producers to substitute more environmentally conserving production techniques and to switch productive resources from, say, energy intensive goods to less energy intensive ones. In this respect the paper seeks to deal with a specific set of circumstances which are far from applicable to every economic sector. As such it seeks to complement the existing, more widely applicable literature - to focus on the role of profits as a key short run transmission mechanism by which energy taxes effect changes in producer behaviour.

We produce evidence to show that the UK is almost certainly open to trade and unlikely to be able to influence world prices for a range of economic activities. Using this as a working assumption we examine the impact of current environmental taxes in the UK on profitability for a wide range of economic sectors. We then de-compose the overall effect of these environmental taxes on profits into that part attributable to fossil energy taxes and that to other environmental taxes. In general we find fossil energy taxes to be much more significant in their effect on profits and that they introduce significant variations between sectors in the profit incentives to switch productive resources away from energy intensive activities.

This paper seeks to address the way in which fossil energy and other environmental taxes provide short run profit incentives to reallocate resources within the domestic economy. It does not 
address carbon leakage (the transfer of production to other countries which have weaker policies on emissions).

\section{REVIEW OF LITERATURE}

A key body of recent literature on energy (and environmental) taxation is that concerned with Environmental Tax Reform (ETR). As Ekins et al (2010) note ETR is not the introduction of new energy taxes but the shifting of the burden of taxation from socially desirable activities such as employment to socially undesirable activities such as those resulting in pollution. Patuelli et al (2005) provide a synthesis of research on ETR up to that date and find that the type of tax is important. They also report that effects on GDP tend to be less clear than effects on employment. Barker et al (2011a) set out models to analyse the potential effects of ETR which combine a variety of interlocking approaches, including input-output and econometric analyses. Barker et al (2011b) apply these models to a possible Europe wide ETR, finding that energy taxes would be effective in increasing energy productivity. Ekins et al (2011) employ a similar comprehensive modelling approach to assess the possible effects of an ETR in the UK. Amongst their findings are that a reduction in energy demand from industry and households but a slight fall in competitiveness. Ekins et al (2012) provide a similar analysis of ETR using computable general equilibrium (CGE) and econometric methods. One finding of direct relevance to this study was the tendency of non-energy intensive sectors to gain at the expense of energy intensive ones. Other recent examples of empirical research using a modelling approach to assess the effects of energy taxes include Sterner (2007) and Hennessy and Tol (2011).

The focus of the ETR literature is on a broad, comprehensive analysis. Both within the ETR framework and separately from it there are also a series of papers which, like this paper, focus on more specific aspects. Sancho (2010) uses a CGE model to assess a potential ETR, finding the elasticity of substitution between labour and capital to be of particular importance. Agnolucci 
(2011) analyses whether long term changes in energy consumption are deterministic or stochastic. Sterner (2012) produces evidence to suggest that fuel taxes in Europe and Japan have caused carbon emissions to be reduced. Peretto (2009) develops a model of energy taxes which looks at resource allocation and in which both market structure and technical change are endogenous. Datta (2010), using evidence from India, examines whether fuel taxes are regressive, finding the opposite. Cremer at al (2010) also consider the issue of whether environmental taxes are regressive, in this case for France, finding environmental taxes to be regressive. Marion and Muehlegger (2011) analyse the incidence of fuel taxes in the US, finding that taxes on fuel suppliers are fully and immediately passed on to fuel users. Markandya and Pemberton (2010) assess fossil energy taxes as a means of ensuring security of supply.

Econometric studies of energy taxes would, for example, include those by Ghalwash (2007), Agnolucci (2009) and Kim et al (2011). Typically these use demand models to identify the effects of taxes on prices. These studies are unquestionably both valid and useful but this paper makes the case that, by considering the effect on prices, such studies are not covering all possible relevant circumstances. In particular, we provide evidence that, for the UK, many industries are sufficiently open to international trade that it must be presumed that the prices involved are world not domestic prices.

In terms of the questions addressed (but not methodology) this paper shares much common ground with Bassi et al (2009), who use a modelling approach to analyse the impacts of energy prices on the competitiveness of individual sectors. The approach of this paper differs in that it sees competitiveness in highly traded sectors as more the ability to be profitable at prevailing world prices. In this respect, our analysis has even more in common with that of Baksi and Green (2007) who see production changes arising from two sources - (a) a shift in production from energy intensive to other sectors and (b) an increase in energy efficiency of individual sectors. 
The approach adopted in this paper is in line with the long standing and continued tradition of using input-output tables to analyse the effects of energy or environmental taxes. Recent work in this tradition includes, for example, Wang et al (2011), who use input-output analysis to examine the effects of carbon taxes on sector competitiveness in China, Llop (2007) and Llop and Pie (2008), who use input-output analysis to identify the effects of carbon taxes on price competitiveness in Catalonia. Our paper owes much to these studies in that we also use an input-output based methodology to identify effects on the competitiveness of sectors in the UK. The main distinction is that this paper uses a different concept of "competitiveness" - the ability to be profitable at given world prices. Other work, for example that of Chamberlain (2009), has used traditional input-output techniques to assess the household burden and economic impact of aspects of US environmental policy. Our approach in this paper is broadly similar to that of Chamberlain (2009) except that we consider the case where the goods and services are internationally traded at given world prices.

Input-output analysis has a long tradition of being applied to environmental issues, dating back to Leontief and Ford (1970). Cornwall and Creedy (1996) used IO analysis to estimate the price effects of carbon taxation in Australia. produced a comparative study of I-O in the UK and Germany. Environmental I-O analysis takes into account environmental inputs both directly and indirectly. For many businesses the emissions of, say, GHGs, take place within complex supply chains rather than directly from fuel or energy consumption (Berners-Lee et al, 2011). However, this is quickly complicated when the relevant inputs are internationally traded. Recent environmentally extended IO tables have been used in various applications including hybrid life cycle assessments (Suh and Huppes, 2005).

Environmentally enhanced input-output tables can be used to support environmental and other policy purposes too (for example, Tukker et al, 2006) including analysis of causes of environmental problems such as use of such resources that result in emissions and environmental 
pollution and prospective effect analysis of policies. The literature suggests that for the analysis of effects of environmental policies environmentally enhanced I-O tables with detailed sector resolution are desirable in order to properly capture the effect on environmental inputs and their costs. However, it is only possible to work with available data - the UK input output tables for the years 2004-2008 in this case. It is partly due to these data limitations and partly because our emphasis is on the impact of energy taxes on the underlying profit incentives at the level of sectors that we use standard rather than environmentally enhanced I-O tables in this paper.

Although this paper does not directly address the issue of carbon leakage it clearly has some bearing on the related policy debate. Readers interested in the related policy issues are referred to: http://ec.europa.eu/clima/policies/ets/leakage/documentation_en.htm

\section{ANALYTICAL FRAMEWORK}

\subsection{Supply and Demand Analysis}

This paper considers the application of fossil energy and other environmental taxes in a specific set of circumstances - where the sector(s) concerned face international competition at given (international) prices. Barker et al (2009), amongst others, recognise that firms cannot pass on the cost of energy taxes to consumers if they are open to trade and face given international prices. This section starts by revising the simple theoretical foundations for such a view. To do this we use a partial equilibrium framework, with its well known limitations.

Figure 1 below provides a supply and demand analysis for an import competing good. The comparable analysis for an export good is presented in Appendix 1 for completeness. Figure 1 deals with three different scenarios. We consider the case where firms face given world prices $\left(\mathrm{p}_{\mathrm{w}}\right)$ and given world supply $\left(\mathrm{S}_{\mathrm{w}}\right)$. Domestic supply and demand is given by D and, initially, $\mathrm{S}$. If the good is non-tradeable initial market equilibrium is at point A. If the good is internationally 
traded domestic supply is determined at point A', with the remainder of consumption being supplied by imports. Now consider the effects of the introduction (or an increase in) taxes on fossil energy or other environmentally unfriendly inputs. Like any increase in input costs this shifts domestic supply inward from $S$ to $S^{*}$. For a non-tradeable good market equilibrium shifts from point A to point B with a corresponding increase in domestic prices. For an import competing good the corresponding change is from point A' to B'. Prices do not change since producers face given world prices but output and profit are reduced. Since prices do not change it is possible to measure this effect on profits, a point explored later.

\section{FIGURE 1}

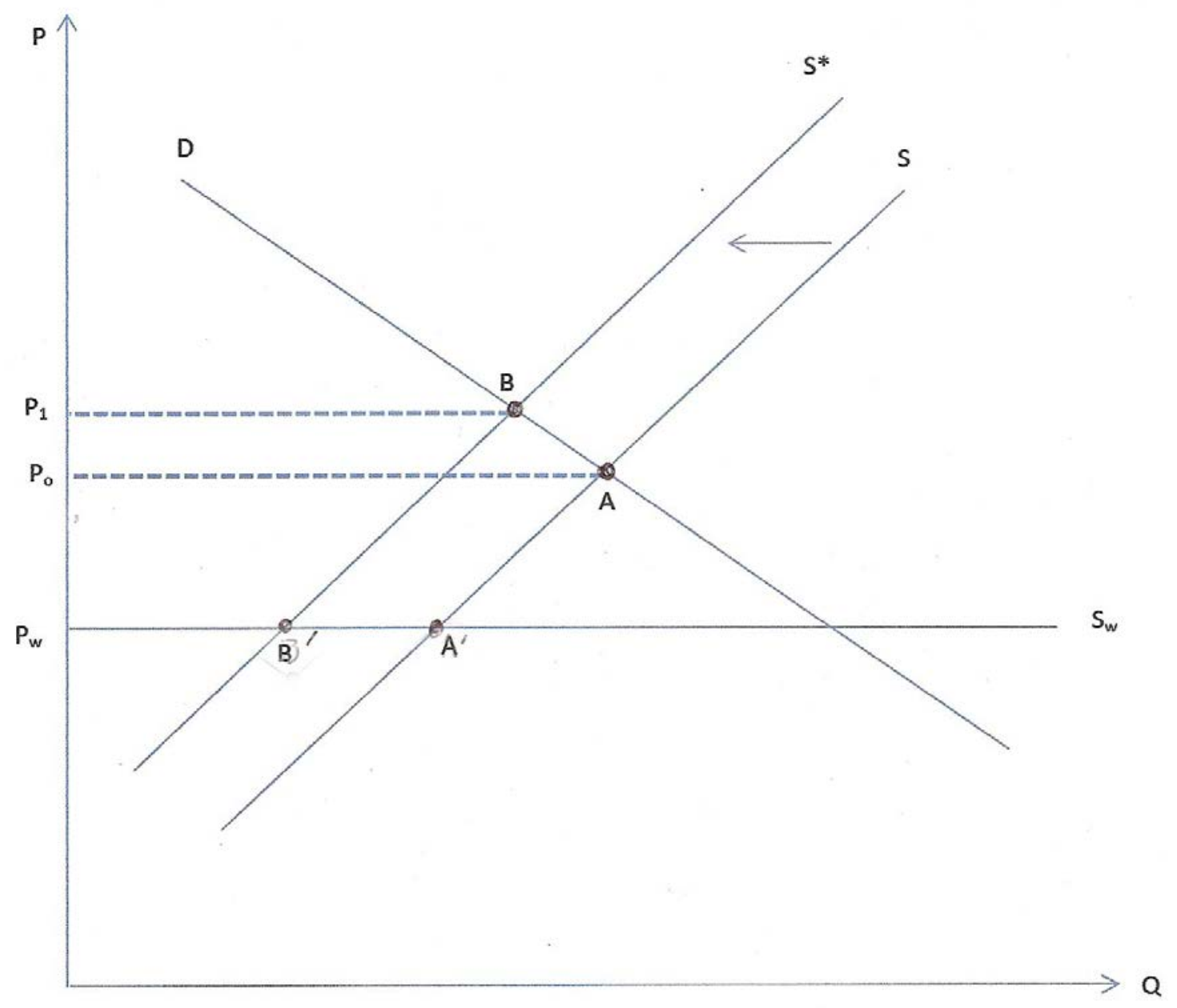




\subsection{Product Differentiation}

One possible objection to the preceding analysis is that it relies on perfect competition and, hence, homogeneous products. Strictly speaking this analysis cannot be applied to circumstances where product differentiation exists. However, economic models dealing with product differentiation cover a range of different circumstances. We would not, for example, argue that an assumption of given international prices would apply to motor vehicles, where international competition is characterised by both product differentiation and a small number of large firms. Some well established models of monopolistic competition such as that of Lancaster (1975) and Dixit and Stiglitz (1977) allow for free entry and a large number of firms. It is characteristic of these "large number" models that each variety of a product faces competition from a number of very close substitutes in the form of other varieties. With free entry these models result in a common equilibrium (market) price and zero monopoly profit. These models have quite strong behavioural similarities to the perfectly competitive model, particularly with respect to the ability of firms to set prices above costs. For this reason we would argue that our analysis provides a reasonable approximation to the behaviour of firms in a wider set of circumstances than the formal analysis permits. Specifically, we would expect to observe a similar link between costs and prices in international markets, even where products are differentiated, provided the number of competitors in such markets is large. This clearly does not apply to all industries but should apply to a good number.

\subsection{Empirical Approach}

The analytical approach taken in this paper is to measure the effect on industry profits of fossil energy and other environmental taxes under scenario (a) above - where firms are open to international trade at given world prices. We recognise that this is only applicable to some 
industries and not others. In particular, it is not applicable to non-tradeables or to industries where monopoly power exists in international markets. For this reason we also provide analysis of the extent to which the outputs of different UK industries are traded and, where possible, the share of the UK in world imports and exports. That is, we provide an analysis of the extent to which different industries are open to international trade and, if so, the extent to which they are likely to be capable of affecting world prices.

Given these assumptions our analysis focuses on seeking to identify the way in which fossil energy and environmental taxes affect the costs and, ultimately, the profits of domestic producers. In this respect it owes much to the literature on the effects of indirect taxes on the profit incentives to undertake foreign direct investment. Recent literature on inward investment, such as the paper by Devereux and Griffith (2003), has emphasised the role of indirect taxes in empirical studies of underlying profit incentives. Work by, for example, Fernandes (2007) has shown that profits can be very sensitive to trade taxes. Our paper is closest in approach to that of Guisinger (1989) who develops measures to assess how various different taxes and similar measures affect profit incentives for investment.

Our approach is to take a set of environmental taxes and to calculate, in effect, the impact of these on gross profits for different sectors of the UK economy. That is, fossil energy taxes are not profit taxes but they can be expressed as what is essentially a profit tax equivalent - the tax on corporate income that would have the same effect on profits as the input tax . Thus, the net incentive effect for industry $\mathrm{j}\left(\mathrm{NIE}_{\mathrm{j}}\right)$ is given as:

$$
\mathrm{NIE}_{\mathrm{j}}=-\left(\Pi_{\mathrm{j}}-\Pi_{\mathrm{j}}^{*}\right) / \Pi^{*}{ }_{\mathrm{j}}
$$

where $\Pi_{\mathrm{j}}$ are "profits” with the fossil energy taxes applied and $\Pi^{*}{ }_{\mathrm{j}}$ profits without these taxes applied. Thus, to measure the effect of actual taxes $\Pi_{\mathrm{j}}$ are reported "profits" and $\Pi^{*}{ }_{\mathrm{j}}$ is calculated from input output data, with inputs revalued to "tax free" prices. We also note that the concept of 
"profit” is one open to a variety of different definitions. For the purposes of our analysis we are constrained by available data and our working definition is gross operating surplus, as defined in the UK input-output tables. Gross operating surplus in this respect is the total revenue (output) of industry $\mathrm{j}$ less the cost of intermediate inputs, compensation of labour and taxes on production (net of subsidies).

\subsection{Short run analysis}

Our analysis is explicitly intended to apply to the short term rather than the long run. That is, it explicitly examines the effect on profit incentives for producers to change behaviour but does not include any response by producers to these incentives. For example, we do not provide any analysis of resulting changes in production techniques or the switching of productive resources from energy intensive to other industries. Our focus is upon the way that fossil energy and other environmental taxes provide profit incentives for these changes in behaviour rather than upon the consequent changes themselves.

The analysis that we present is also short term in another sense. We assume given world prices and that a purely national UK policy of taxation will not change these. However, the adoption of genuinely global policies to reduce, say, carbon emissions would affect world prices. In this respect our key assumptions can also be seen as a "first mover" advantage. Porter and Van der Linde (1995a) have pointed to some of the possible advantages of appropriate and early policies to encourage innovation with respect to energy use. Moreover, Porter and Van der Linde (1995b) point to the possibilities of an early mover advantage through policy induced changes in energy use. Our analysis addresses the case where the UK is amongst the leaders in imposing energy taxes; where there are early mover advantages from the introduction of fossil energy taxes even if such taxes are non-existent or weaker in trading partners. 


\section{ANALYSIS OF OPENNESS TO TRADE BY SECTOR}

The assumptions that the UK faces given world prices is at the core of our analysis. This can be broken down into two subsidiary assumptions: (a) that a significant proportion of economic sectors in the UK are open to international trade and (b) that it has a sufficiently small share of global markets that it is unlikely to affect world prices. This section presents evidence on both of these.

Table 1 presents two standard indicators of the importance of trade to any individual sector. Firstly, import penetration, measures the percentage of domestic consumption accounted for by imports, in effect an import "market share”. Secondly, export to sales ratios measure the percentage of domestic production which is exported. It should be noted that it is not necessary for both indicators to be substantial for a good to be regarded as "traded". Much trade theory would predict that goods tend to be either exported or imported, not both.

The results presented in Table 1 show that almost all goods sectors in the UK are substantially traded and, in many cases, are highly exposed to international trade. The few exceptions, arguably, include printing and publishing, building materials and metal forging and pressing. For utilities and services the picture is different. The majority of service sectors exhibit no or low exposure to international trade but there are some important exceptions. These include water and air transport, wholesaling, computer services, research and development, and other business services. For a small number of industries such as office machinery and jewellery export to sales ratios are recorded in excess of $100 \%$. These sectors involve processing of imported inputs within the same industrial category (for example, precious stones added to jewellery). Exports are calculated using the final value of the good, including the re-exported components, and in this respect overstate true “exports”. 


\begin{tabular}{|c|c|c|c|c|}
\hline \multirow[t]{3}{*}{ Input-output sector } & \multicolumn{2}{|c|}{ Import penetration \% } & \multicolumn{2}{|c|}{ Export to sales ratio \% } \\
\hline & 2008 & Average & 2008 & Average \\
\hline & & 2004-2008 & & 2004-2008 \\
\hline Agriculture & $23.5 \%$ & $23.8 \%$ & $6.7 \%$ & $6.2 \%$ \\
\hline Forestry & $15.5 \%$ & $15.9 \%$ & $5.0 \%$ & $5.7 \%$ \\
\hline Fishing & $18.9 \%$ & $17.8 \%$ & $31.4 \%$ & $33.4 \%$ \\
\hline Coal extraction & $72.6 \%$ & $61.6 \%$ & $12.8 \%$ & $6.7 \%$ \\
\hline Oil and gas extraction & $37.3 \%$ & $31.5 \%$ & $39.4 \%$ & $37.0 \%$ \\
\hline Metal ores extraction, Other mining and quarrying & $45.7 \%$ & $43.5 \%$ & $82.9 \%$ & $83.1 \%$ \\
\hline Meat processing & $19.4 \%$ & $18.4 \%$ & $9.3 \%$ & $7.3 \%$ \\
\hline Fish and fruit processing & $27.3 \%$ & $24.9 \%$ & $15.9 \%$ & $14.2 \%$ \\
\hline Oils and fats & $44.3 \%$ & $32.3 \%$ & $38.6 \%$ & $26.3 \%$ \\
\hline Dairy products & $16.6 \%$ & $15.8 \%$ & $11.1 \%$ & $11.2 \%$ \\
\hline Grain milling and starch & $17.4 \%$ & $14.3 \%$ & $17.5 \%$ & $16.2 \%$ \\
\hline Animal feed & $9.2 \%$ & $9.4 \%$ & $11.3 \%$ & $10.0 \%$ \\
\hline Bread, biscuits, etc & $11.8 \%$ & $10.3 \%$ & $7.2 \%$ & $6.4 \%$ \\
\hline Sugar & $24.5 \%$ & $22.7 \%$ & $19.8 \%$ & $15.7 \%$ \\
\hline Confectionery & $15.4 \%$ & $13.9 \%$ & $13.1 \%$ & $12.2 \%$ \\
\hline Other food products & $25.1 \%$ & $20.5 \%$ & $19.1 \%$ & $16.1 \%$ \\
\hline Alcoholic beverages & $18.9 \%$ & $18.2 \%$ & $58.2 \%$ & $51.1 \%$ \\
\hline Soft drinks and mineral waters & $13.7 \%$ & $13.1 \%$ & $7.1 \%$ & $5.9 \%$ \\
\hline Tobacco products & $10.0 \%$ & $9.9 \%$ & $23.9 \%$ & $25.5 \%$ \\
\hline Textile fibres, Textile weaving, Textile finishing & $26.6 \%$ & $27.8 \%$ & $49.3 \%$ & $51.4 \%$ \\
\hline Made-up textiles, Carpets and rugs, Other textiles, & $30.3 \%$ & $28.1 \%$ & $46.4 \%$ & $41.7 \%$ \\
\hline Wearing apparel and fur products & $30.7 \%$ & $29.4 \%$ & $84.6 \%$ & $70.6 \%$ \\
\hline Leather goods, Footwear & $40.5 \%$ & $39.2 \%$ & $85.6 \%$ & $91.4 \%$ \\
\hline Wood and wood products & $28.9 \%$ & $29.0 \%$ & $4.7 \%$ & $5.1 \%$ \\
\hline Pulp, paper and paperboard & $50.3 \%$ & $49.8 \%$ & $62.2 \%$ & $52.4 \%$ \\
\hline Paper and paperboard products & $10.2 \%$ & $9.0 \%$ & $11.6 \%$ & $10.8 \%$ \\
\hline Printing and publishing & $7.0 \%$ & $6.5 \%$ & $9.1 \%$ & $8.5 \%$ \\
\hline Coke ovens, refined petroleum \& nuclear fuel & $24.9 \%$ & $20.4 \%$ & $60.6 \%$ & $52.4 \%$ \\
\hline Industrial gases and dyes & $18.8 \%$ & $18.4 \%$ & $31.0 \%$ & $31.9 \%$ \\
\hline Inorganic chemicals, Organic chemicals & $36.5 \%$ & $35.7 \%$ & $63.4 \%$ & $60.2 \%$ \\
\hline Fertilisers, Plastics \& Synthetic resins etc, Pesticides & $37.4 \%$ & $32.7 \%$ & $64.4 \%$ & $58.2 \%$ \\
\hline Paints, varnishes, printing ink etc & $16.2 \%$ & $14.6 \%$ & $36.2 \%$ & $30.9 \%$ \\
\hline Pharmaceuticals & $31.6 \%$ & $32.4 \%$ & $101.6 \%$ & $92.9 \%$ \\
\hline Soap and toilet preparations & $17.1 \%$ & $15.4 \%$ & $63.2 \%$ & $54.4 \%$ \\
\hline Other Chemical products, Man-made fibres & $41.1 \%$ & $37.1 \%$ & $96.4 \%$ & $93.6 \%$ \\
\hline Rubber products & $36.9 \%$ & $33.3 \%$ & $49.9 \%$ & $45.6 \%$ \\
\hline Plastic products & $22.9 \%$ & $21.1 \%$ & $23.7 \%$ & $21.7 \%$ \\
\hline Glass and glass products & $23.1 \%$ & $21.4 \%$ & $23.4 \%$ & $22.8 \%$ \\
\hline Ceramic goods & $29.8 \%$ & $27.3 \%$ & $38.5 \%$ & $36.9 \%$ \\
\hline Structural clay products, Cement, lime and plaster & $4.7 \%$ & $4.7 \%$ & $5.7 \%$ & $5.9 \%$ \\
\hline Articles of concrete, stone etc & $10.2 \%$ & $9.5 \%$ & $9.7 \%$ & $9.9 \%$ \\
\hline Iron and steel, Non-ferrous metals, Metal castings & $40.5 \%$ & $36.0 \%$ & $101.5 \%$ & $80.1 \%$ \\
\hline Structural metal products & $9.4 \%$ & $7.7 \%$ & $9.6 \%$ & $8.6 \%$ \\
\hline Metal boilers and radiators & $26.7 \%$ & $23.7 \%$ & $18.6 \%$ & $16.1 \%$ \\
\hline Metal forging, pressing, etc & $0.0 \%$ & $0.0 \%$ & $0.0 \%$ & $0.0 \%$ \\
\hline Cutlery, tools etc & $35.6 \%$ & $33.7 \%$ & $56.9 \%$ & $59.5 \%$ \\
\hline Other metal products & $30.3 \%$ & $27.8 \%$ & $41.8 \%$ & $36.2 \%$ \\
\hline Mechanical power equipment & $42.1 \%$ & $39.9 \%$ & $90.6 \%$ & $81.3 \%$ \\
\hline General purpose machinery & $33.2 \%$ & $31.6 \%$ & $47.1 \%$ & $44.5 \%$ \\
\hline Agricultural machinery & $43.7 \%$ & $36.5 \%$ & $78.7 \%$ & $66.6 \%$ \\
\hline Machine tools & $49.1 \%$ & $47.5 \%$ & $93.8 \%$ & $82.4 \%$ \\
\hline
\end{tabular}


Table 1 (continued): Indicators of Tradeability by Sector, UK, 2004-2008

\begin{tabular}{|c|c|c|c|c|}
\hline \multirow[t]{3}{*}{ Input-output sector } & \multicolumn{2}{|c|}{ Import penetration \% } & \multicolumn{2}{|c|}{ Export to sales ratio \% } \\
\hline & 2008 & Average & 2008 & Average \\
\hline & & 2004-2008 & & 2004-2008 \\
\hline Special purpose machinery & $34.5 \%$ & $34.8 \%$ & $87.3 \%$ & $80.7 \%$ \\
\hline Weapons and ammunition & $17.3 \%$ & $14.7 \%$ & $16.2 \%$ & $18.6 \%$ \\
\hline Domestic appliances nec & $32.6 \%$ & $29.3 \%$ & $33.1 \%$ & $27.0 \%$ \\
\hline Office machinery \& computers & $52.9 \%$ & $53.1 \%$ & $118.6 \%$ & $122.2 \%$ \\
\hline Electric motors and generators etc, Insulated wire and & $37.9 \%$ & $35.3 \%$ & $69.3 \%$ & $59.8 \%$ \\
\hline Electrical equipment nec & $36.5 \%$ & $33.7 \%$ & $60.8 \%$ & $56.4 \%$ \\
\hline Electronic components & $47.6 \%$ & $51.6 \%$ & $57.8 \%$ & $99.0 \%$ \\
\hline Transmitters for TV, radio and phone & $60.4 \%$ & $67.9 \%$ & $97.2 \%$ & $228.2 \%$ \\
\hline Receivers for TV and radio & $34.8 \%$ & $35.1 \%$ & $95.8 \%$ & $103.4 \%$ \\
\hline Medical and precision instruments & $35.3 \%$ & $34.0 \%$ & $77.6 \%$ & $73.0 \%$ \\
\hline Motor vehicles & $38.1 \%$ & $38.2 \%$ & $63.5 \%$ & $57.3 \%$ \\
\hline Shipbuilding and repair & $17.7 \%$ & $22.2 \%$ & $39.3 \%$ & $38.5 \%$ \\
\hline Other transport equipment & $22.4 \%$ & $21.6 \%$ & $19.3 \%$ & $18.9 \%$ \\
\hline Aircraft and spacecraft & $46.2 \%$ & $44.4 \%$ & $71.7 \%$ & $75.9 \%$ \\
\hline Furniture & $23.5 \%$ & $21.3 \%$ & $12.4 \%$ & $10.9 \%$ \\
\hline Jewellery and related products & $42.2 \%$ & $42.2 \%$ & $413.2 \%$ & $333.6 \%$ \\
\hline Sports goods and toys & $20.7 \%$ & $18.3 \%$ & $100.1 \%$ & $79.7 \%$ \\
\hline Miscellaneous manufacturing nec \& recycling & $14.7 \%$ & $14.1 \%$ & $9.7 \%$ & $10.3 \%$ \\
\hline Electricity production and distribution & $1.0 \%$ & $1.0 \%$ & $0.5 \%$ & $0.5 \%$ \\
\hline Gas distribution & $0.1 \%$ & $0.1 \%$ & $0.0 \%$ & $0.0 \%$ \\
\hline Water supply & $0.3 \%$ & $0.2 \%$ & $2.4 \%$ & $2.6 \%$ \\
\hline Construction & $0.5 \%$ & $0.3 \%$ & $0.0 \%$ & $0.0 \%$ \\
\hline Motor vehicle distribution and repair, automotive fuel ret & $0.5 \%$ & $0.5 \%$ & $0.5 \%$ & $0.6 \%$ \\
\hline Wholesale distribution & $21.9 \%$ & $46.5 \%$ & $4.8 \%$ & $2.1 \%$ \\
\hline Retail distribution & $1.6 \%$ & $1.4 \%$ & $0.9 \%$ & $0.8 \%$ \\
\hline Hotels, catering, pubs etc & $12.8 \%$ & $12.5 \%$ & $1.3 \%$ & $1.2 \%$ \\
\hline Railway transport & $8.3 \%$ & $9.0 \%$ & $0.5 \%$ & $0.4 \%$ \\
\hline Other land transport & $4.6 \%$ & $4.5 \%$ & $1.0 \%$ & $1.1 \%$ \\
\hline Water transport & $21.6 \%$ & $25.1 \%$ & $0.3 \%$ & $0.3 \%$ \\
\hline Air Transport & $29.4 \%$ & $32.4 \%$ & $0.1 \%$ & $0.1 \%$ \\
\hline Ancillary Transport services & $2.8 \%$ & $3.3 \%$ & $0.7 \%$ & $0.7 \%$ \\
\hline Postal and courier services & $4.9 \%$ & $4.5 \%$ & $0.3 \%$ & $0.2 \%$ \\
\hline Telecommunications & $8.4 \%$ & $7.3 \%$ & $1.4 \%$ & $1.3 \%$ \\
\hline Banking and finance & $8.6 \%$ & $8.6 \%$ & $0.5 \%$ & $0.6 \%$ \\
\hline Insurance and pension funds & $1.1 \%$ & $1.0 \%$ & $7.3 \%$ & $6.9 \%$ \\
\hline Auxiliary financial services & $6.6 \%$ & $6.1 \%$ & $4.6 \%$ & $4.2 \%$ \\
\hline Owning and dealing in real estate & $0.0 \%$ & $0.0 \%$ & $5.6 \%$ & $4.5 \%$ \\
\hline Letting of dwellings & $0.8 \%$ & $0.8 \%$ & $0.7 \%$ & $0.7 \%$ \\
\hline Estate agent activities & $0.5 \%$ & $0.6 \%$ & $11.6 \%$ & $10.0 \%$ \\
\hline Renting of machinery etc & $5.0 \%$ & $4.5 \%$ & $48.9 \%$ & $42.3 \%$ \\
\hline Computer services & $5.1 \%$ & $4.3 \%$ & $51.9 \%$ & $58.4 \%$ \\
\hline Research and development & $20.5 \%$ & $17.9 \%$ & $0.4 \%$ & $0.3 \%$ \\
\hline Legal activities & $2.2 \%$ & $1.9 \%$ & $0.0 \%$ & $0.0 \%$ \\
\hline Accountancy services & $3.0 \%$ & $2.8 \%$ & $0.7 \%$ & $0.7 \%$ \\
\hline Market research, management consultancy & $2.4 \%$ & $1.8 \%$ & $2.2 \%$ & $1.9 \%$ \\
\hline Architectural activities and technical consultancy & $4.8 \%$ & $4.9 \%$ & $0.5 \%$ & $0.6 \%$ \\
\hline Advertising & $7.1 \%$ & $5.8 \%$ & $0.0 \%$ & $0.0 \%$ \\
\hline Other business services & $17.5 \%$ & $15.8 \%$ & $0.0 \%$ & $0.0 \%$ \\
\hline Education & $0.5 \%$ & $0.5 \%$ & $0.0 \%$ & $0.0 \%$ \\
\hline Health and veterinary services & $1.4 \%$ & $1.4 \%$ & $0.4 \%$ & $0.4 \%$ \\
\hline Social work activities & $0.0 \%$ & $0.0 \%$ & $4.5 \%$ & $4.0 \%$ \\
\hline Sewage and Sanitary services & $2.2 \%$ & $1.8 \%$ & $1.2 \%$ & $1.1 \%$ \\
\hline Recreational services & $11.6 \%$ & $11.2 \%$ & $1.6 \%$ & $1.5 \%$ \\
\hline Other service activities & $1.0 \%$ & $1.0 \%$ & $0.6 \%$ & $0.7 \%$ \\
\hline
\end{tabular}


The results presented in Table 1 show much of UK economic activity to be exposed to foreign competition either in domestic markets or export markets or both. The next issue to address is the extent to which world prices are given from the perspective of the UK. Ideally this question would be directly addressed by an analysis of prices. However, such analysis is lengthy, complex and fraught with both data limitations and conceptual difficulties. As an alternative we adopt a simpler but less precise approach. For a sample of some 50 commodities we measure the share of the UK in total world exports. This approach is similar to that recommended by Krugman (2000) and, therefore, has a measure of acceptance as a valid means of assessing the likelihood of being able to affect world prices. Our sample consists exclusively of goods, not services, for reasons of data availability. Thus, we take a small market share to imply that it is unlikely (but not certain) that the UK exerts an influence over world prices.

The results of this analysis are presented in Table 2. For only two of the products in our sample did the UK exhibit a share of world exports greater than 10\% (annual average 2004-8) - in beverages and in printed matter. For much of our sample it is possible to assert with some confidence that it is unlikely that the UK exerts any significant influence over world prices. The share of the UK in total world exports rarely exceeds 3\% for most of our sample. There are, no doubt, some special cases where such a low market share might lead a country to be a price maker rather than a price taker but special cases, by definition, do not apply systematically. We conclude, therefore, that our evidence is sufficient to suggest that the assumption that UK prices are driven by world prices that are, in turn, given represents a significant part of economic activity in the UK.

Taken overall our findings support our working assumption that (world) prices are not likely to respond in the short or medium term to national taxes imposed by the UK. This conclusion does not apply universally. It applies in particular to the many production sectors but only to a minority of service sectors. 


\begin{tabular}{|c|c|c|c|c|}
\hline \multirow[t]{3}{*}{ Product Name } & \multicolumn{2}{|c|}{ UK Share of World Exports } & \multicolumn{2}{|c|}{ UK Share of World Imports } \\
\hline & 2008 & Average & 2008 & Average \\
\hline & & 2004-2008 & & 2004-2008 \\
\hline Meat and edible meat offal & $1.79 \%$ & $1.75 \%$ & $6.78 \%$ & $8.25 \%$ \\
\hline Fish \& shellfish & $2.50 \%$ & $2.80 \%$ & $3.22 \%$ & $3.38 \%$ \\
\hline Dairy products; eggs; natural honey & $2.18 \%$ & $2.70 \%$ & $6.15 \%$ & $6.82 \%$ \\
\hline Edible vegetables and certain roots and tubers. & $0.98 \%$ & $1.08 \%$ & $8.97 \%$ & $9.78 \%$ \\
\hline Edible fruit and nuts & $0.37 \%$ & $0.43 \%$ & $7.06 \%$ & $7.91 \%$ \\
\hline Cereals & $0.97 \%$ & $1.12 \%$ & $1.61 \%$ & $1.86 \%$ \\
\hline Animal and vegetable fats $\&$ oils & $1.05 \%$ & $1.44 \%$ & $3.06 \%$ & $3.29 \%$ \\
\hline Sugars and sugar confectionery. & $2.67 \%$ & $2.83 \%$ & $6.41 \%$ & $6.86 \%$ \\
\hline Cocoa and cocoa preparations. & $2.55 \%$ & $2.97 \%$ & $6.36 \%$ & $6.93 \%$ \\
\hline Beverages, spirits and vinegar. & $9.64 \%$ & $10.72 \%$ & $9.45 \%$ & $11.06 \%$ \\
\hline Tobacco and manufactured tobacco substitutes & $2.60 \%$ & $3.96 \%$ & $2.14 \%$ & $2.39 \%$ \\
\hline Salt; sulphur; earth \& stone; plastering materials & $1.92 \%$ & $3.06 \%$ & $1.47 \%$ & $2.26 \%$ \\
\hline Mineral fuels, oils \& their products & $2.56 \%$ & $3.03 \%$ & $3.02 \%$ & $3.10 \%$ \\
\hline Inorganic chemicals & $1.98 \%$ & $3.81 \%$ & $2.83 \%$ & $3.93 \%$ \\
\hline Organic chemicals. & $4.29 \%$ & $4.80 \%$ & $4.19 \%$ & $4.93 \%$ \\
\hline Pharmaceutical products. & $8.02 \%$ & $8.65 \%$ & $5.10 \%$ & $5.83 \%$ \\
\hline Fertilisers. & $0.35 \%$ & $0.65 \%$ & $2.00 \%$ & $2.11 \%$ \\
\hline Soap, organic surface-active agents, washing preparations & $4.98 \%$ & $5.84 \%$ & $5.49 \%$ & $5.83 \%$ \\
\hline Albuminoidal subs; modified starches; glues; enzymes & $2.39 \%$ & $3.36 \%$ & $3.58 \%$ & $4.24 \%$ \\
\hline Explosives; pyrotechnic products; matches & $1.49 \%$ & $4.24 \%$ & $1.69 \%$ & $3.69 \%$ \\
\hline Photographic or cinematographic goods. & $5.94 \%$ & $5.98 \%$ & $5.17 \%$ & $5.22 \%$ \\
\hline Plastics and articles thereof. & $2.62 \%$ & $3.10 \%$ & $3.76 \%$ & $4.24 \%$ \\
\hline Rubber and articles thereof. & $2.30 \%$ & $2.88 \%$ & $3.69 \%$ & $4.16 \%$ \\
\hline Articles of leather; saddlery/harness; travel goods & $1.62 \%$ & $1.85 \%$ & $5.52 \%$ & $5.59 \%$ \\
\hline Wood and articles of wood; wood charcoal. & $0.62 \%$ & $0.72 \%$ & $5.00 \%$ & $5.39 \%$ \\
\hline Pulp of wood and of other fibrous cellulosic material & $2.26 \%$ & $2.14 \%$ & $2.62 \%$ & $3.15 \%$ \\
\hline Paper \& paperboard; articles trhereof & $2.65 \%$ & $2.85 \%$ & $6.01 \%$ & $6.75 \%$ \\
\hline Printed books, newspapers etc & $9.65 \%$ & $11.96 \%$ & $7.23 \%$ & $7.90 \%$ \\
\hline Man-made filaments. & $1.57 \%$ & $2.46 \%$ & $2.56 \%$ & $3.06 \%$ \\
\hline Man-made staple fibres. & $1.78 \%$ & $2.84 \%$ & $2.54 \%$ & $2.92 \%$ \\
\hline Wadding, felt \& nonwoven; yarns; twine, cordage, & $2.49 \%$ & $3.05 \%$ & $4.94 \%$ & $5.41 \%$ \\
\hline Carpets and other textile floor coverings. & $3.28 \%$ & $3.46 \%$ & $11.54 \%$ & $13.33 \%$ \\
\hline Knitted or crocheted fabrics. & $0.91 \%$ & $1.24 \%$ & $0.89 \%$ & $1.11 \%$ \\
\hline Apparel \& clothing accessories, knitted & $1.60 \%$ & $1.81 \%$ & $6.98 \%$ & $7.43 \%$ \\
\hline Apparel \& clothing accessories, not knitted & $2.00 \%$ & $2.02 \%$ & $6.93 \%$ & $7.35 \%$ \\
\hline Other made up textile articles & $2.16 \%$ & $2.25 \%$ & $5.34 \%$ & $5.98 \%$ \\
\hline Footwear & $1.42 \%$ & $1.47 \%$ & $5.63 \%$ & $6.40 \%$ \\
\hline Ceramic products. & $2.14 \%$ & $2.68 \%$ & $5.14 \%$ & $5.74 \%$ \\
\hline Glass and glassware. & $2.35 \%$ & $2.76 \%$ & $3.89 \%$ & $4.28 \%$ \\
\hline Iron and steel. & $2.64 \%$ & $3.17 \%$ & $1.88 \%$ & $2.31 \%$ \\
\hline Articles of iron or steel. & $2.44 \%$ & $2.98 \%$ & $3.33 \%$ & $4.00 \%$ \\
\hline Copper and articles thereof. & $1.82 \%$ & $1.92 \%$ & $2.15 \%$ & $2.52 \%$ \\
\hline Aluminium and articles thereof. & $2.77 \%$ & $3.12 \%$ & $3.37 \%$ & $3.46 \%$ \\
\hline Tools, implements, cutlery, of base metal & $3.07 \%$ & $4.59 \%$ & $4.06 \%$ & $4.99 \%$ \\
\hline Electrical machinery & $2.13 \%$ & $3.58 \%$ & $3.17 \%$ & $3.93 \%$ \\
\hline Aircraft, spacecraft, and parts thereof. & $0.02 \%$ & $4.81 \%$ & $0.01 \%$ & $6.22 \%$ \\
\hline Ships, boats and floating structures. & $1.57 \%$ & $1.73 \%$ & $0.92 \%$ & $1.60 \%$ \\
\hline Optical, photographic, measuring, precision instruments & $3.98 \%$ & $4.54 \%$ & $3.86 \%$ & $4.41 \%$ \\
\hline Clocks and watches and parts thereof. & $1.37 \%$ & $1.60 \%$ & $3.73 \%$ & $3.91 \%$ \\
\hline Musical instruments; parts and access of such art & $1.64 \%$ & $2.02 \%$ & $5.49 \%$ & $6.47 \%$ \\
\hline Arms and ammunition; parts and accessories thereo & $1.60 \%$ & $7.97 \%$ & $3.68 \%$ & $8.01 \%$ \\
\hline Furniture; bedding, mattresses etc & $1.90 \%$ & $2.18 \%$ & $6.31 \%$ & $6.69 \%$ \\
\hline Source: United Nations COMTRADE database & & & & \\
\hline
\end{tabular}




\section{ANALYSIS OF PROFIT TAX EQUIVALENTS}

In this section we consider how existing UK fossil energy and other environmental taxes have affected gross profits and, in particular, how they have affected profit incentives to produce one good or service rather than another. As noted previously our definition of "profit" is determined by the available data and is gross operating surplus as defined by the UK input-output tables.

Table 3 presents estimates of the effect of existing UK taxes on the environment, mainly on energy, on gross operating surplus for our sample of sectors. The taxes involved are:

- duty on hydrocarbon oils, and

- the climate change levy (affecting coal, gas and electricity)

- Landfill tax

- Aggregates levy

There are other taxes - vehicle excise duty and air passenger duty - whose origins, arguably, lie in transport rather than environmental policy but which have taken on an environmental aspect. An obvious difficulty with these is to decide how far they are environmental as opposed to transport policies. Even were they to be fully environmental taxes their ultimate effects on user industries would still be hard to measure accurately in our analytical framework, particularly when taxes such as air passenger duty are targeted on consumers rather than producers. For these reasons they are not included in our analysis.

The method of calculation was to calculate a net incentive effect (see equation 1) based on the difference between actual gross operating surplus and that estimated without the presence of these taxes on energy. Those sectors for which our "open economy" assumption (that the sector 
is sufficiently open to international competition to be trading at world prices) is dubious are included for completeness but marked by an asterisk.

The results are presented in Table 3, which identifies the implied effect on gross operating surplus of (a) energy taxes (hydrocarbon fuels duty and climate change levy) (b) other environmental taxes (aggregates levy and landfill tax) and (c) the combined effects of both sets of taxes. These are reported as averages for the period 2004-2008 and as annual estimates (for the combined set only).

Unsurprisingly, there are considerable variations in the effects of fossil energy and other environmental taxes on gross operating surplus. Given that the revenues from energy taxes, and from the duty on hydrocarbon oils in particular, dominate environmental and related tax receipts (see Appendix 2) it is not at all surprising that the industries most affected are energy intensive. Road, water and air transport are all fuel intensive sectors, whose payments in energy and other environmental taxes represent more than $50 \%$ of their gross operating surplus. In each case this is almost wholly attributable to energy rather than other environmental taxes. Our estimates may, however, be overstated for air transport since aviation fuel is exempt. Other industries with high rates that are attributable to energy (fuel) use include fishing (47\%), rail transport (45\%) and travel agents/tour operators (36\%).

The estimated rates of tax are measured in relation to gross operating surplus and, in consequence, are not just affected by their use of fuel, energy, aggregates or waste disposal. They are also affected by underlying profitability. This creates another category of industry that is highly affected by energy and environmental taxes - those which are not the highest energy users but which have sufficiently low profitability to be much affected by energy and environmental taxes. Examples include oils and fats processing (gross operating surplus [GOS] 6.5\% of turnover, energy and environmental taxes $55 \%$ of GOS), inorganic chemicals (GOS 7.6\% of 
turnover, energy taxes etc. 58\% of GOS) and paper products (GOS 2.5\% of turnover, taxes 36\% of GOS). The industries little affected by energy and other environmental taxes include leather goods (1.6\% of GOS), pharmaceuticals (1.2\% of GOS), weapons and ammunition (1.4\%), construction (1.5\%) and banking and finance (1.4\%).

The contrast between the sectors heavily affected by energy and other environmental taxes and those little affected underlines the high degree of variation in the effects of these taxes between one sector and another. This variation in the impact on "competitiveness" between energy intensive and non-energy intensive sectors is consistent with the findings of a number of other authors including Stern (2006) and Ekins et al (2012).

These results suggest that the effect of current UK fossil energy and other environmental taxes is broadly equivalent to introducing a "profit" tax which varies by economic sector. For example, our estimates suggest that it would be roughly equivalent to taxing profits by $26 \%$ for cement, lime and plaster but only by $2.6 \%$ for computers and electronics. The sectors more affected are not just the most energy intensive but also those with more marginal profitability such as dairy products (29\%). There can be little doubt, therefore, that these taxes provide significant profit incentives for investors to divert resources and, hence, future production from one sector to another. They also provide strong incentives for the most energy intensive sectors to adopt more energy efficient techniques or to perish. The downside, however, is that this provides little incentive for the majority of less energy intensive activities to do likewise. Our finding that the burden of energy taxes falls disproportionately on a small number of energy intensive industries supports the findings of the effects of other energy policies on sector competitiveness reported in Hourcade et al (2007) and Grubb et al (2009).

The likelihood of the contraction of several key sectors is not in itself a problem. Indeed, as discussed earlier, a key route by which fossil energy and other environmental taxes work in 
reducing overall carbon emissions is to reduce production in those sectors which make most intensive use of carbon. Altering profit incentives is an effective way to get producer to reallocate resources accordingly. Nor do the authors believe that creating profit disincentives for the usage of carbon is necessarily a problem if other countries do not do likewise. If such changes happen later then there may be advantages in being one of the first movers to make the necessary changes.

Finally, the results presented in Table 3 show that the high rates of tax levied on energy and hydrocarbon oils in particular have a substantially more powerful effect on profits. Given the huge receipts from duty on hydrocarbon oils in comparison to the receipts for other environmental taxes (see Appendix 2) this should be no surprise. Amongst the highest taxed industries for environmental (landfill and aggregates) taxes are inorganic chemicals (6.8\% of GOS) and basic metals (5\% of GOS). The majority of industries exhibit rates which are substantially less than $1 \%$ of gross operating surplus (GOS). Energy taxes (hydrocarbon oils and the climate change levy) are typically much higher in relation to GOS. Industries with high rates include many mentioned previously plus postal services (50\% of GOS) and wood products (23\% of GOS). Again a number of industries exhibit rate less than $2 \%$ of GOS, including construction, sewerage, insurance and tobacco products. 


\begin{tabular}{|c|c|c|c|c|c|c|c|c|c|}
\hline \multirow[t]{4}{*}{ Input-output sector } & \multicolumn{3}{|c|}{ Annual Average 2004-2008 } & \multirow{3}{*}{$\begin{array}{c}\text { Both sets } \\
\text { of taxes }\end{array}$} & \multicolumn{2}{|c|}{ Annual estimates } & & & \\
\hline & \multirow{3}{*}{\begin{tabular}{|l|} 
GOS as \\
a \% of \\
total output \\
\end{tabular}} & \multirow{3}{*}{\begin{tabular}{|c} 
Energy \\
Taxes* \\
\% of Gos
\end{tabular}} & \multirow{3}{*}{\begin{tabular}{|c|} 
Other \\
Taxes* \\
$\%$ of GOS \\
\end{tabular}} & & \multicolumn{5}{|c|}{ Enery and other environmental taxes (combined) } \\
\hline & & & & & \multicolumn{2}{|c|}{ as a $\%$ of GOS } & \multirow[b]{2}{*}{2006} & \multirow[b]{2}{*}{2007} & \multirow[b]{2}{*}{2008} \\
\hline & & & & combined & 2004 & 2005 & & & \\
\hline Agriculture & $35.02 \%$ & $14.86 \%$ & $0.01 \%$ & $14.87 \%$ & $15.45 \%$ & $15.32 \%$ & $13.97 \%$ & $17.37 \%$ & $12.25 \%$ \\
\hline Forestry* & $13.12 \%$ & $30.56 \%$ & $0.05 \%$ & $30.61 \%$ & $34.14 \%$ & $31.94 \%$ & $29.50 \%$ & $30.07 \%$ & $27.40 \%$ \\
\hline Fishing & $32.95 \%$ & $46.73 \%$ & $0.10 \%$ & $46.83 \%$ & $71.88 \%$ & $58.35 \%$ & $38.02 \%$ & $32.39 \%$ & $33.53 \%$ \\
\hline Oil and gas extraction & $68.79 \%$ & $0.85 \%$ & $0.00 \%$ & $0.85 \%$ & $1.07 \%$ & $0.98 \%$ & $0.77 \%$ & $0.80 \%$ & $0.62 \%$ \\
\hline Metal ores extraction, Other mining and quarrying & $15.16 \%$ & $22.01 \%$ & $9.03 \%$ & $31.04 \%$ & $32.75 \%$ & $31.57 \%$ & $38.38 \%$ & $34.52 \%$ & $17.99 \%$ \\
\hline Meat processing & $4.31 \%$ & $19.62 \%$ & $0.46 \%$ & $20.08 \%$ & $15.63 \%$ & $20.16 \%$ & $21.15 \%$ & $24.30 \%$ & $19.16 \%$ \\
\hline Fish and fruit processing & $7.28 \%$ & $5.42 \%$ & $0.18 \%$ & $5.59 \%$ & $4.66 \%$ & $4.20 \%$ & $4.86 \%$ & $6.77 \%$ & $7.47 \%$ \\
\hline Oils and fats processing & $6.56 \%$ & $55.15 \%$ & $0.05 \%$ & $55.19 \%$ & $78.75 \%$ & $56.98 \%$ & $42.51 \%$ & $45.50 \%$ & $52.22 \%$ \\
\hline Dairy products & $4.11 \%$ & $28.38 \%$ & $0.27 \%$ & $28.65 \%$ & $23.07 \%$ & $29.38 \%$ & $32.04 \%$ & $30.48 \%$ & $28.27 \%$ \\
\hline Grain milling and starch & $6.95 \%$ & $4.88 \%$ & $0.08 \%$ & $4.96 \%$ & $5.59 \%$ & $5.22 \%$ & $5.10 \%$ & $4.18 \%$ & $4.73 \%$ \\
\hline Animal feed* & $5.99 \%$ & $21.71 \%$ & $0.17 \%$ & $21.88 \%$ & $20.36 \%$ & $19.52 \%$ & $23.19 \%$ & $23.96 \%$ & $22.36 \%$ \\
\hline Bread, biscuits, etc & $13.40 \%$ & $10.40 \%$ & $0.06 \%$ & $10.46 \%$ & $8.23 \%$ & $9.36 \%$ & $10.84 \%$ & $12.47 \%$ & $11.37 \%$ \\
\hline Other food products & $13.75 \%$ & $5.16 \%$ & $0.09 \%$ & $5.24 \%$ & $5.05 \%$ & $4.94 \%$ & $6.34 \%$ & $5.44 \%$ & $4.45 \%$ \\
\hline Alcoholic beverages & $19.63 \%$ & $10.68 \%$ & $0.06 \%$ & $10.74 \%$ & $8.71 \%$ & $10.77 \%$ & $10.19 \%$ & $12.41 \%$ & $11.64 \%$ \\
\hline Soft drinks \& mineral waters & $17.56 \%$ & $5.58 \%$ & $0.04 \%$ & $5.62 \%$ & $6.34 \%$ & $4.87 \%$ & $5.52 \%$ & $5.71 \%$ & $5.67 \%$ \\
\hline Tobacco products & $34.56 \%$ & $0.38 \%$ & $0.01 \%$ & $0.39 \%$ & $0.48 \%$ & $0.38 \%$ & $0.38 \%$ & $0.39 \%$ & $0.30 \%$ \\
\hline Textiles & $10.18 \%$ & $7.60 \%$ & $0.12 \%$ & $7.72 \%$ & $10.96 \%$ & $10.73 \%$ & $7.81 \%$ & $5.26 \%$ & $3.85 \%$ \\
\hline Wearing apparel & $26.21 \%$ & $3.44 \%$ & $0.30 \%$ & $3.74 \%$ & $4.48 \%$ & $3.53 \%$ & $3.47 \%$ & $3.58 \%$ & $3.65 \%$ \\
\hline Leather goods, Footwear & $23.21 \%$ & $1.57 \%$ & $0.05 \%$ & $1.62 \%$ & $2.27 \%$ & $1.89 \%$ & $1.35 \%$ & $1.22 \%$ & $1.38 \%$ \\
\hline Wood and wood products & $8.87 \%$ & $22.54 \%$ & $0.06 \%$ & $22.60 \%$ & $27.87 \%$ & $25.44 \%$ & $20.48 \%$ & $18.88 \%$ & $20.36 \%$ \\
\hline Paper and paper products & $2.49 \%$ & $34.30 \%$ & $1.46 \%$ & $35.77 \%$ & $32.40 \%$ & $38.88 \%$ & $40.31 \%$ & $38.76 \%$ & $28.50 \%$ \\
\hline Printing And Reproduction Of Recorded Media * & $10.88 \%$ & $2.90 \%$ & $0.05 \%$ & $2.96 \%$ & $5.20 \%$ & $2.59 \%$ & $2.33 \%$ & $2.32 \%$ & $2.34 \%$ \\
\hline Industrial gases, inorganic chemicals and fertilisers & $7.63 \%$ & $50.84 \%$ & $6.83 \%$ & $57.67 \%$ & $82.05 \%$ & $62.97 \%$ & $55.17 \%$ & $44.91 \%$ & $43.22 \%$ \\
\hline Paints, varnishes, printing ink etc & $10.60 \%$ & $7.45 \%$ & $0.73 \%$ & $8.18 \%$ & $6.15 \%$ & $6.99 \%$ & $9.61 \%$ & $8.02 \%$ & $10.14 \%$ \\
\hline Pharmaceuticals & $24.85 \%$ & $1.14 \%$ & $0.03 \%$ & $1.17 \%$ & $1.79 \%$ & $1.25 \%$ & $1.03 \%$ & $1.02 \%$ & $0.75 \%$ \\
\hline Soap and toilet preparations & $12.69 \%$ & $3.42 \%$ & $0.05 \%$ & $3.47 \%$ & $3.88 \%$ & $3.04 \%$ & $4.13 \%$ & $3.97 \%$ & $2.33 \%$ \\
\hline Dyestuffs and agro-chemicals & $16.08 \%$ & $10.89 \%$ & $0.13 \%$ & $11.03 \%$ & $15.07 \%$ & $11.44 \%$ & $11.43 \%$ & $9.38 \%$ & $7.82 \%$ \\
\hline Other Chemical products, Man-made fibres & $7.72 \%$ & $45.27 \%$ & $0.18 \%$ & $45.45 \%$ & $29.77 \%$ & $68.55 \%$ & $44.18 \%$ & $45.45 \%$ & $39.26 \%$ \\
\hline Rubber and plastic products & $6.79 \%$ & $15.49 \%$ & $0.12 \%$ & $15.60 \%$ & $13.31 \%$ & $13.21 \%$ & $14.96 \%$ & $17.48 \%$ & $19.06 \%$ \\
\hline Glass, refractory, ceramicv and stone products & $8.19 \%$ & $14.10 \%$ & $6.50 \%$ & $20.59 \%$ & $14.14 \%$ & $15.28 \%$ & $18.02 \%$ & $17.74 \%$ & $37.79 \%$ \\
\hline Cement, lime, plaster and articles thereof* & $11.24 \%$ & $20.97 \%$ & $5.24 \%$ & $26.21 \%$ & $31.13 \%$ & $24.08 \%$ & $22.85 \%$ & $27.07 \%$ & $25.90 \%$ \\
\hline Other basic metals and casting & $4.20 \%$ & $9.06 \%$ & $4.96 \%$ & $14.02 \%$ & $13.31 \%$ & $12.39 \%$ & $16.69 \%$ & $15.99 \%$ & $11.72 \%$ \\
\hline Fabricated metal products & $11.50 \%$ & $8.42 \%$ & $0.04 \%$ & $8.46 \%$ & $10.04 \%$ & $7.24 \%$ & $7.86 \%$ & $8.02 \%$ & $9.14 \%$ \\
\hline Weapons and ammunition & $15.56 \%$ & $1.44 \%$ & $0.00 \%$ & $1.44 \%$ & $1.50 \%$ & $1.24 \%$ & $1.40 \%$ & $1.86 \%$ & $1.21 \%$ \\
\hline Computers, electronics and optical products & $13.02 \%$ & $2.53 \%$ & $0.02 \%$ & $2.55 \%$ & $3.52 \%$ & $2.80 \%$ & $2.30 \%$ & $2.24 \%$ & $1.87 \%$ \\
\hline Electrical equipment & $9.14 \%$ & $11.40 \%$ & $0.03 \%$ & $11.42 \%$ & $9.68 \%$ & $11.32 \%$ & $12.32 \%$ & $13.72 \%$ & $10.08 \%$ \\
\hline Electronic components & $5.08 \%$ & $18.17 \%$ & $0.07 \%$ & $18.24 \%$ & $17.79 \%$ & $18.04 \%$ & $16.35 \%$ & $18.89 \%$ & $20.12 \%$ \\
\hline Motor vehicles & $1.47 \%$ & $5.52 \%$ & $0.06 \%$ & $5.58 \%$ & $13.02 \%$ & $7.70 \%$ & $8.14 \%$ & $10.41 \%$ & $-11.38 \%$ \\
\hline Ship and boat building & $3.88 \%$ & $14.51 \%$ & $0.22 \%$ & $14.73 \%$ & $22.01 \%$ & $18.85 \%$ & $13.25 \%$ & $8.42 \%$ & $11.13 \%$ \\
\hline Aircraft and spacecraft & $2.84 \%$ & $17.74 \%$ & $0.15 \%$ & $17.90 \%$ & $13.81 \%$ & $13.37 \%$ & $15.82 \%$ & $16.63 \%$ & $29.86 \%$ \\
\hline Other transport equipment & $11.92 \%$ & $4.11 \%$ & $0.03 \%$ & $4.14 \%$ & $3.85 \%$ & $2.34 \%$ & $1.96 \%$ & $2.35 \%$ & $10.17 \%$ \\
\hline Furniture & $10.17 \%$ & $11.70 \%$ & $0.07 \%$ & $11.77 \%$ & $11.54 \%$ & $11.72 \%$ & $11.09 \%$ & $13.35 \%$ & $11.14 \%$ \\
\hline Other manufacturing & $15.26 \%$ & $4.86 \%$ & $1.47 \%$ & $6.33 \%$ & $7.33 \%$ & $6.07 \%$ & $6.20 \%$ & $6.35 \%$ & $5.69 \%$ \\
\hline Repair and maintenance of ships and boats & $7.26 \%$ & $9.41 \%$ & $0.12 \%$ & $9.53 \%$ & $15.89 \%$ & $10.04 \%$ & $10.68 \%$ & $6.35 \%$ & $4.71 \%$ \\
\hline Repair and maintenance of aircraft and spacecraft & $4.62 \%$ & $16.17 \%$ & $0.18 \%$ & $16.35 \%$ & $5.09 \%$ & $5.87 \%$ & $5.98 \%$ & $8.50 \%$ & $56.29 \%$ \\
\hline Other repair and installation & $12.36 \%$ & $3.89 \%$ & $0.02 \%$ & $3.92 \%$ & $4.38 \%$ & $4.29 \%$ & $3.80 \%$ & $3.69 \%$ & $3.43 \%$ \\
\hline Electricity production \& distribution* & $18.18 \%$ & $11.31 \%$ & $0.01 \%$ & $11.32 \%$ & $16.01 \%$ & $13.88 \%$ & $8.85 \%$ & $9.50 \%$ & $8.37 \%$ \\
\hline Gas distribution* & $5.97 \%$ & $12.82 \%$ & $0.02 \%$ & $12.84 \%$ & $14.16 \%$ & $16.67 \%$ & $11.41 \%$ & $11.64 \%$ & $10.30 \%$ \\
\hline
\end{tabular}




\begin{tabular}{|c|c|c|c|c|c|c|c|c|c|}
\hline \multirow[t]{4}{*}{ Input-output sector } & \multicolumn{3}{|c|}{ Annual Average 2004-2008 } & \multirow{4}{*}{$\begin{array}{c}\text { Both sets } \\
\text { of taxes } \\
\text { combined }\end{array}$} & \multicolumn{2}{|c|}{ Annual estimates } & & & \\
\hline & \multirow{3}{*}{\begin{tabular}{|l|} 
GOS as \\
a \% of \\
total output \\
\end{tabular}} & \multirow{3}{*}{\begin{tabular}{|l} 
Energy \\
Taxes* \\
\% of GOS
\end{tabular}} & \multirow{3}{*}{\begin{tabular}{|c|} 
Other \\
Taxes* \\
\% of GOS
\end{tabular}} & & \multicolumn{5}{|c|}{ Enery and other environmental taxes (combined) } \\
\hline & & & & & \multicolumn{2}{|c|}{ as a $\%$ of GOS } & \multirow[b]{2}{*}{2006} & \multirow[b]{2}{*}{2007} & \multirow[b]{2}{*}{2008} \\
\hline & & & & & 2004 & 2005 & & & \\
\hline Water supply* & $49.60 \%$ & $2.06 \%$ & $0.04 \%$ & $2.10 \%$ & $2.45 \%$ & $1.98 \%$ & $1.95 \%$ & $2.15 \%$ & $1.96 \%$ \\
\hline Sewerage * & $43.96 \%$ & $1.88 \%$ & $0.70 \%$ & $2.58 \%$ & $2.84 \%$ & $2.81 \%$ & $2.67 \%$ & $2.48 \%$ & $2.08 \%$ \\
\hline Waste collection and disposal * & $15.32 \%$ & $2.40 \%$ & $8.10 \%$ & $10.50 \%$ & $10.45 \%$ & $10.38 \%$ & $10.19 \%$ & $10.90 \%$ & $10.56 \%$ \\
\hline Remediation and other waste management * & $5.58 \%$ & $13.96 \%$ & $0.00 \%$ & $13.96 \%$ & $23.92 \%$ & $18.44 \%$ & $14.47 \%$ & $7.94 \%$ & $5.04 \%$ \\
\hline Construction of buildings* & $22.30 \%$ & $1.14 \%$ & $0.32 \%$ & $1.47 \%$ & $1.65 \%$ & $1.45 \%$ & $1.33 \%$ & $1.41 \%$ & $1.48 \%$ \\
\hline Civil engineering* & $17.69 \%$ & $3.86 \%$ & $0.42 \%$ & $4.29 \%$ & $5.88 \%$ & $4.72 \%$ & $4.28 \%$ & $3.47 \%$ & $3.09 \%$ \\
\hline Specialised construction* & $20.95 \%$ & $1.58 \%$ & $0.34 \%$ & $1.92 \%$ & $2.33 \%$ & $1.92 \%$ & $1.72 \%$ & $1.94 \%$ & $1.68 \%$ \\
\hline Motor vehicle distribution \& repair, fuel* & $17.91 \%$ & $6.18 \%$ & $0.07 \%$ & $6.25 \%$ & $8.26 \%$ & $6.29 \%$ & $5.78 \%$ & $5.46 \%$ & $5.45 \%$ \\
\hline Wholesale distribution* & $14.03 \%$ & $15.26 \%$ & $0.11 \%$ & $15.37 \%$ & $19.73 \%$ & $16.49 \%$ & $12.76 \%$ & $12.26 \%$ & $15.61 \%$ \\
\hline Retail distribution* & $20.07 \%$ & $4.91 \%$ & $0.03 \%$ & $4.95 \%$ & $5.66 \%$ & $4.97 \%$ & $4.60 \%$ & $4.95 \%$ & $4.55 \%$ \\
\hline Railway transport* & $4.26 \%$ & $44.29 \%$ & $0.30 \%$ & $44.59 \%$ & $68.42 \%$ & $44.37 \%$ & $43.79 \%$ & $36.70 \%$ & $29.69 \%$ \\
\hline Other land transport* & $15.11 \%$ & $68.24 \%$ & $0.06 \%$ & $68.30 \%$ & $87.11 \%$ & $70.98 \%$ & $60.83 \%$ & $64.62 \%$ & $57.93 \%$ \\
\hline Water transport & $12.63 \%$ & $59.00 \%$ & $0.08 \%$ & $59.09 \%$ & $\mathrm{n} / \mathrm{a}$ & $65.47 \%$ & $64.42 \%$ & $57.71 \%$ & $48.75 \%$ \\
\hline Air Transport & $17.44 \%$ & $66.99 \%$ & $0.11 \%$ & $67.10 \%$ & $78.91 \%$ & $69.86 \%$ & $60.86 \%$ & $65.09 \%$ & $60.77 \%$ \\
\hline Ancillary Transport services* & $15.50 \%$ & $2.22 \%$ & $0.10 \%$ & $2.31 \%$ & $2.75 \%$ & $2.54 \%$ & $2.06 \%$ & $2.30 \%$ & $1.92 \%$ \\
\hline Postal and courier services* & $5.12 \%$ & $29.94 \%$ & $0.40 \%$ & $30.21 \%$ & $\mathrm{n} / \mathrm{a}$ & $40.19 \%$ & $31.68 \%$ & $22.81 \%$ & $26.15 \%$ \\
\hline Accommodation & $12.94 \%$ & $12.28 \%$ & $0.12 \%$ & $12.40 \%$ & $15.61 \%$ & $13.63 \%$ & $11.35 \%$ & $10.84 \%$ & $10.56 \%$ \\
\hline Food and beverage service activities & $13.72 \%$ & $9.26 \%$ & $0.11 \%$ & $9.38 \%$ & $11.25 \%$ & $10.39 \%$ & $8.58 \%$ & $8.86 \%$ & $7.81 \%$ \\
\hline Publishing & $14.91 \%$ & $1.17 \%$ & $0.02 \%$ & $1.19 \%$ & $1.97 \%$ & $0.97 \%$ & $1.01 \%$ & $1.03 \%$ & $0.97 \%$ \\
\hline Motion Picture, Video, TV, Sound Recording & $15.57 \%$ & $3.86 \%$ & $0.09 \%$ & $3.95 \%$ & $4.31 \%$ & $3.89 \%$ & $3.55 \%$ & $3.83 \%$ & $4.15 \%$ \\
\hline Programming And Broadcasting Activities & $32.72 \%$ & $1.05 \%$ & $0.02 \%$ & $1.06 \%$ & $1.31 \%$ & $1.12 \%$ & $1.02 \%$ & $1.01 \%$ & $0.86 \%$ \\
\hline Telecommunications* & $22.95 \%$ & $3.71 \%$ & $0.03 \%$ & $3.74 \%$ & $4.44 \%$ & $4.05 \%$ & $3.53 \%$ & $3.58 \%$ & $3.08 \%$ \\
\hline Banking and finance* & $31.06 \%$ & $1.37 \%$ & $0.01 \%$ & $1.37 \%$ & $1.63 \%$ & $1.56 \%$ & $1.36 \%$ & $1.48 \%$ & $0.85 \%$ \\
\hline Insurance and pension funds* & $17.11 \%$ & $1.47 \%$ & $0.01 \%$ & $1.48 \%$ & $2.37 \%$ & $1.08 \%$ & $1.80 \%$ & $1.01 \%$ & $1.17 \%$ \\
\hline Auxiliary financial services* & $9.61 \%$ & $5.76 \%$ & $0.13 \%$ & $5.89 \%$ & $9.71 \%$ & $5.88 \%$ & $5.21 \%$ & $4.24 \%$ & $4.40 \%$ \\
\hline Owning,dealing and renting of real estate* & $52.51 \%$ & $0.09 \%$ & $0.00 \%$ & $0.09 \%$ & $0.10 \%$ & $0.09 \%$ & $0.09 \%$ & $0.09 \%$ & $0.09 \%$ \\
\hline Estate agent activities* & $32.64 \%$ & $0.51 \%$ & $0.03 \%$ & $0.53 \%$ & $0.37 \%$ & $0.39 \%$ & $0.48 \%$ & $0.48 \%$ & $0.95 \%$ \\
\hline Renting of machinery etc & $29.24 \%$ & $2.44 \%$ & $0.05 \%$ & $2.49 \%$ & $2.97 \%$ & $2.81 \%$ & $2.37 \%$ & $2.05 \%$ & $2.26 \%$ \\
\hline Computer services & $16.65 \%$ & $2.74 \%$ & $0.03 \%$ & $2.77 \%$ & $3.38 \%$ & $3.05 \%$ & $2.47 \%$ & $2.59 \%$ & $2.35 \%$ \\
\hline Information services & $18.57 \%$ & $3.92 \%$ & $0.03 \%$ & $3.95 \%$ & $5.43 \%$ & $5.13 \%$ & $3.71 \%$ & $3.45 \%$ & $2.04 \%$ \\
\hline Research and development & $12.19 \%$ & $15.88 \%$ & $0.19 \%$ & $16.07 \%$ & $10.33 \%$ & $8.15 \%$ & $9.99 \%$ & $23.31 \%$ & $28.57 \%$ \\
\hline Legal activities* & $35.14 \%$ & $1.24 \%$ & $0.01 \%$ & $1.25 \%$ & $1.56 \%$ & $1.38 \%$ & $1.05 \%$ & $1.17 \%$ & $1.08 \%$ \\
\hline Accountancy services* & $33.88 \%$ & $1.85 \%$ & $0.02 \%$ & $1.87 \%$ & $2.82 \%$ & $1.93 \%$ & $1.58 \%$ & $1.71 \%$ & $1.30 \%$ \\
\hline Advertising and market research* & $18.82 \%$ & $1.99 \%$ & $0.09 \%$ & $2.09 \%$ & $2.50 \%$ & $2.73 \%$ & $1.80 \%$ & $2.07 \%$ & $1.34 \%$ \\
\hline Architectural activities \& Tech. Consult* & $13.62 \%$ & $4.52 \%$ & $0.03 \%$ & $4.55 \%$ & $5.08 \%$ & $4.51 \%$ & $4.82 \%$ & $4.64 \%$ & $3.69 \%$ \\
\hline Other professional And technical activities & $18.20 \%$ & $3.35 \%$ & $0.03 \%$ & $3.38 \%$ & $4.25 \%$ & $3.47 \%$ & $2.79 \%$ & $4.20 \%$ & $2.19 \%$ \\
\hline Education* & $5.58 \%$ & $9.30 \%$ & $0.08 \%$ & $9.38 \%$ & $11.43 \%$ & $9.71 \%$ & $9.15 \%$ & $9.01 \%$ & $7.59 \%$ \\
\hline Veterinary Activities* & $26.61 \%$ & $1.05 \%$ & $0.07 \%$ & $1.12 \%$ & $1.75 \%$ & $1.00 \%$ & $1.06 \%$ & $0.93 \%$ & $0.86 \%$ \\
\hline Human Health Activities* & $11.30 \%$ & $2.43 \%$ & $0.15 \%$ & $2.58 \%$ & $3.42 \%$ & $2.65 \%$ & $2.17 \%$ & $2.37 \%$ & $2.27 \%$ \\
\hline Employment Activities * & $13.92 \%$ & $2.02 \%$ & $0.04 \%$ & $2.06 \%$ & $2.61 \%$ & $1.88 \%$ & $1.54 \%$ & $1.78 \%$ & $2.49 \%$ \\
\hline Travel agency, tour operator, reservation services & $4.08 \%$ & $23.46 \%$ & $0.57 \%$ & $24.03 \%$ & $36.23 \%$ & $18.84 \%$ & $16.30 \%$ & $18.76 \%$ & $29.98 \%$ \\
\hline Creative, Arts And Entertainment Activities & $29.61 \%$ & $1.50 \%$ & $0.04 \%$ & $1.54 \%$ & $1.50 \%$ & $1.27 \%$ & $1.34 \%$ & $1.82 \%$ & $1.75 \%$ \\
\hline Gambling And Betting Activities & $15.21 \%$ & $5.94 \%$ & $0.13 \%$ & $6.07 \%$ & $8.08 \%$ & $7.05 \%$ & $6.53 \%$ & $5.30 \%$ & $3.36 \%$ \\
\hline Sports a musement and recreation activities & $8.02 \%$ & $7.59 \%$ & $0.19 \%$ & $7.78 \%$ & $6.70 \%$ & $6.11 \%$ & $5.94 \%$ & $8.89 \%$ & $11.25 \%$ \\
\hline \multicolumn{10}{|c|}{ Sources: 1 . Supply and Use Tables 1997-2010, Office of National Statistics } \\
\hline \multicolumn{10}{|l|}{ 2. Tax and Duty Bulletins, HMRC Statistics } \\
\hline \multicolumn{10}{|c|}{ Notes: '1. "Energy taxes" comprise the hydrocarbons oil duty and the climate change levy } \\
\hline 2. "Other environmental taxes" comprise the aggre & s levy and lan & dfill tax & & & & & & & \\
\hline
\end{tabular}




\section{CONCLUSIONS}

In this paper we present the case that in certain circumstances fossil energy and other environmental taxes mainly or wholly operate by affecting profits to producers in the short run and not by changing prevailing market prices. These circumstances are where (a) the relevant fossil energy and environmental taxes are national rather than global (b) the goods and services concerned are internationally traded and (c) the country concerned faces given world prices. It might be thought that such circumstances apply in theory but not in practice so we provide evidence to support the hypothesis that such conditions are credible for a significant part of the UK economy. Although we do not provide evidence to extend this to other countries it is likely that, if such conditions prevail in the UK, they also prevail in a significant number of other countries.

Even though the consequences of facing given world prices means that national taxes do not effectively change prices the resulting change in profits provides the key incentive to reduce the use of environmentally damaging inputs. They provide incentives for user industries to (a) adopt more environmentally favourable production techniques or (b) reduce the use of such inputs by reducing the output of the user industries. We provide an analysis of the short run effects of fossil energy and other environmental taxes on profits (GOS) in the UK at the industry level. Our results suggest that, in particular, the burden of adjustment to fossil energy taxes falls on a comparatively small range of fossil energy intensive industries. 


\section{REFERENCES}

Agnolucci, .P, 2009. The Effect of the German and British Environmental Taxation Reforms: A Simple Assessment. Energy Policy, 37, 3043-3051.

Agnolucci, P., 2011. Is Environmental Tax Reform an Appropriate Policy for Industrial Sectors with Different Energy Intensities? An Analysis of UK Industrial Sectors. In: Ekins, P., and Speck, S., (eds.), (2011) Environmental Tax Reform (ETR): A Policy for Green Growth, Oxford: Oxford University Press.

Baksi, S., Green, C., 2007. Calculating economy-wide energy intensity decline rate: The role of sectoral output and energy shares. Energy Policy, 35, 6457-6466.

Barker, T., Ekins, P., Junankar, S., Pollitt, H., Summerton, P., 2009. The Competitiveness of European Environmental Fiscal Reforms, European Review of Energy Markets, 3, 1-33.

Barker, T., Lutz, C., Meyer, B., Polliitt H., 2011a. Models for Projecting the Impacts of ETR. In: Ekins, P., and Speck, S., (eds.), (2011) Environmental Tax Reform (ETR): A Policy for Green Growth, Oxford: Oxford University Press.

Barker, T., Lutz, C., Meyer, B., Polliitt H., Speck, S., 2011b. Modelling an ETR for Europe. In: Ekins, P., and Speck, S., (eds.), (2011) Environmental Tax Reform (ETR): A Policy for Green Growth, Oxford: Oxford University Press.

Bassi, A., Yuidken, J., Ruth, M., 2009. Climate policy impacts on the competitiveness of energy-intensive manufacturing sectors. Energy Policy, 37, 3052-3060.

Berners-Lee, M., Howard, D.C., Moss, J., Kavianto, K., Scott, W.A., 2011. Greenhouse gas foot printing for small businesses-the use of Input-Output data. Science of the Total Environment, 409, 883-891.

Chamberlain, A., 2009. Who pays for climate policy? New estimates of the household burden and economic impact of a U.S. cap-and-trade system. Tax foundation working paper, (6).

Cremer, H., Gahvari, F., Ladoux, N., 2010. Environmental Tax Design with Endogenous Earnings Abilities, Journal of Environmental Economics and Management, 59, 82-93.

Cornwall, A., Creedy, J., 1996. Carbon taxation, prices and inequality in Australia. Fiscal Studies, 17, 39-61.

Datta, A., 2010. The Incidence of Fuel Taxation in India. Energy Economics, 32, S26-S33.

Devereux, M. P., Griffith, R., 2003. Evaluating Tax Policy for Location Decisions, International Tax and Public Finance, 10, 107-126. 
Dixit, A.K. and Stiglitz, J.E., 1977, Monopolistic Competition and Optimum Product Diversity, American Economic Review, 67, 297-08.

Ekins, P., Kleinmann, H., Bell, S., Venn, A., 2010. Two Unannounced Environmental Tax Reforms in the UK: The Fuel Duty Escalator and Income Tax in the 1990s. Ecological Economics, 69, 1561-1568.

Ekins, P., Summerton, P., Thoung, C., Lee, D., 2011. A Major Environmental Tax Reform for the UK: Results for the Economy, Employment and the Environment, Environmental Resource Economics, 50, 447-474

Ekins, P., Pollitt, H., Summerton, P., Chewpreecha, U., 2012. Increasing Carbon and Material Productivity Through Environmental Tax Reform, Energy Policy, 42, 365-376.

Fernandes, A.M. , 2007. Trade Policy, Trade Volumes And Plant-Level Productivity In Colombian Manufacturing Industries. Journal of International Economics, 71, 52-71.

Ghalwash, T., 2007. Energy Taxes as a Signalling Device: An Empirical Analysis of Consumer Preferences. Energy Policy, 35, 29-38.

Grubb, M., Brewer, T.L., Sato, M., Heilmayr, R., Dora, F., 2009. Climate Policy and Industrial Competitiveness: Ten Insights from Europe on the EU Emissions Trading System. Climate \& Energy Paper Series 09, Climate Strategies, Cambridge

Guisinger, S., 1989. Total Protection: A New Measure of the Impact of Government Interventions on Investment Profitability. Journal of International Business Studies, 20, 280-295.

Hennessy, H., Tol, R., 2011. The impact of tax reform on new car purchases in Ireland. Energy Policy, 39, 70597067.

Hourcade, J.-C., Demailly, D., Neuhoff, K., Sato, M., 2007. Differentiation and Dynamics of EU ETS Industrial Competitiveness Impacts. Climate Strategies Report, Climate Strategies, Cambridge.

HMRC (2011) Environmental Taxes. Available from :

http://customs.hmrc.gov.uk/channelsPortalWebApp/channelsPortalWebApp.portal?_nfpb=true\&_pageLabel=pageE xcise_RatesCodesTools [Accessed July 2011]

House of Commons Environmental Audit Committee, 2011. Budget 2011 and Environmental taxes: Sixth report of Session 2010-12, The Stationary Office Limited, London.

Kim, Y. D., Han, H. O., Moon, Y.S., 2011. The empirical effects of a gasoline tax on CO2 emissions reductions from transportation sector in Korea. Energy Policy, 39, 981-989.

Krugman, P. R. (2000). Technology, trade and factor prices, Journal of International Economics, 50, 51-71. 
Lancaster, K, 1975. Socially Optimal Product Differentiation, American Economic Review, 65, 567-585.

Leontief,W., Ford, D., 1970. Environmental repercussions and the economic structure: and input-output approach.

Review of Economic Statistics, 52, 262-271.

Llop, M, 2007. Economic structure and pollution intensity within the environmental input-output framework. Energy Policy, 35, 3410-3417.

Llop, M and Pie, L, 2008, Input-output analysis of alternative policies implemented on the energy activities: An application for Catalonia. Energy Policy, 36, 1642-1648.

Marion, J., and Muehlegger, E., 2011. Fuel Tax Incidence and Supply Conditions, Journal of Public Economics, 95, 1202-1212.

Markandya, A., and Permberton, M., 2010. Energy Security, Energy Modelling and Uncertainty, Energy Policy, 38, 1609-1613.

Office of National Statistics, 2011. Environmental Accounts June 2011, ONS, UK.

Patuelli, P., Nijkamp, P., Pels, E., 2005. Environmenetal Tax Reform and the Double Dividend: A Meta-Analytical Performance Assessment, Ecological Economics, 55, 564-583.

Peretto, P.E., 2009. Energy Taxes and Endogenous Technological Change, Journal of Environmental Economics and Management,57, 269-283.

Porter, M. E., \& Van der Linde, C. (1995a). Toward a New Conception of the Environment-Competitiveness Relationship. Journal of Economic Perspectives, 9, 97-118.

Porter, M. E., \& Van der Linde, C. (1995b). Green and Competitive: Ending The Stalemate., Harvard Business Review, 73, 120-134.

Sancho, F., 2010. Double Dividend Effectiveness Of Energy Tax Policies and the Elasticity of Substitution: A CGE Appraisal, Energy Policy, 38, 2927-2933.

Stern, N., 2006, The Economics of Climate Change: The Stern Review, Cambridge University Press, Cambridge. Sterner, T., 2007. Fuel taxes: An important instrument for climate policy. Energy Policy, 35, 3194-3202.

Sterner, T., 2012. Distributional Effects of Taxing Transport Fuel, Energy Policy. 41, 75-83.

Suh, S., Huppes, G.,2005. Methods in life cycle inventory of a product. Journal of Cleaner Production, 13, 687-697.

Tukker, A., Huppes, G., van Oers, L., Heijungs,R., 2006. Environmentally Extended Input-Output Tables and Models for Europe, Institute for Prospective Technological Studies, Spain.

Wang, X, Feng Li, J and Xiong Zhang, Y, 2011. An analysis on the short-term sectoral competitiveness impact of carbon tax in China. Energy Policy, 39, 4144-4152. 


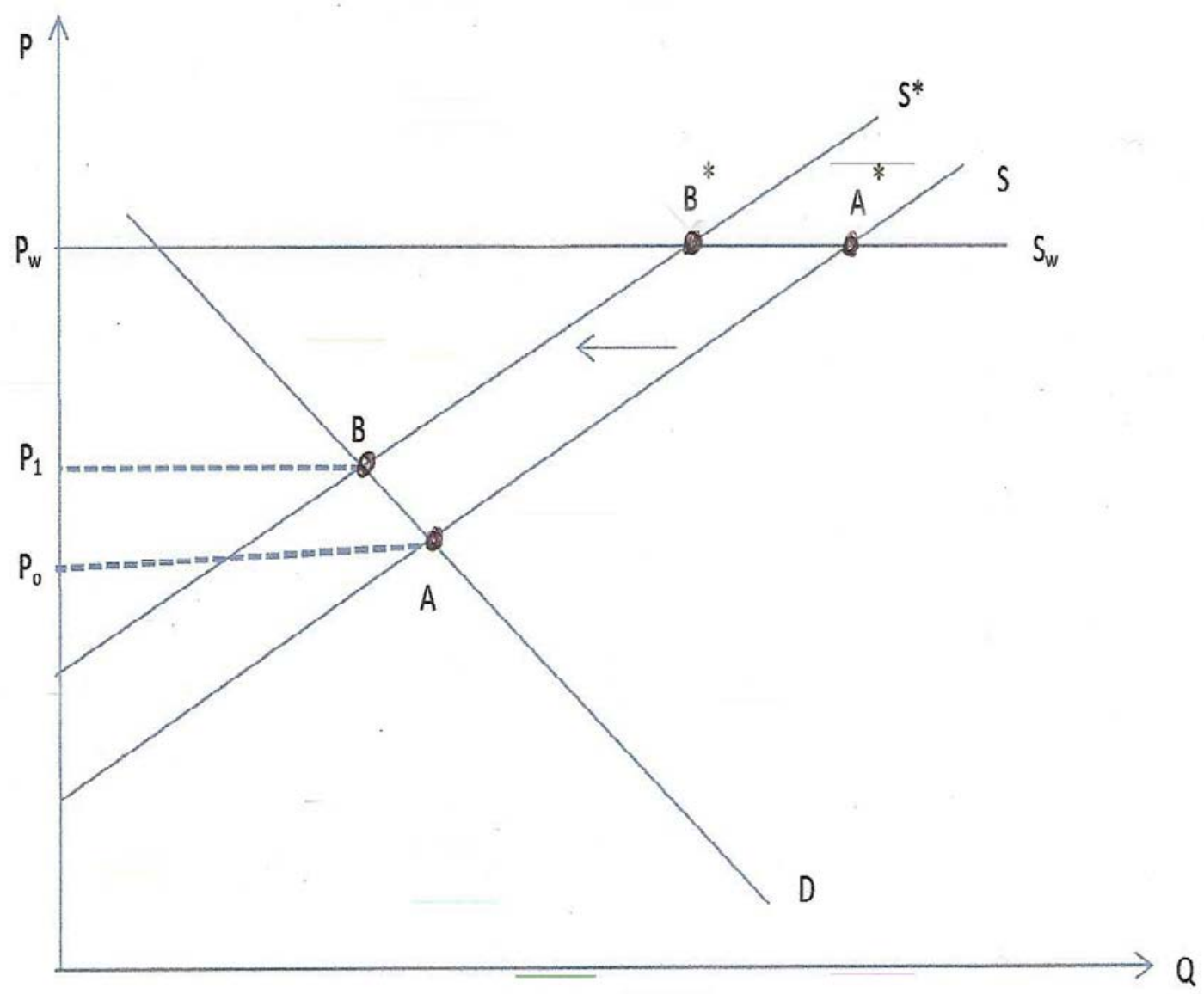

The objective of this analysis is to demonstrate that the theoretical effects of an energy tax on supply conditions is essentially the same for an export good as that presented for an import competing good in section 3. The UK sector is presumed to face given world prices in export markets. Equilibrium for the exportable good is initially at point $\mathrm{A}^{*}$, given by the intersection of the domestic supply curve (S) and the world supply curve $\left(S_{\mathrm{w}}\right)$. In contrast, domestic equilibrium for a non-tradeable would be at point A, given by the intersection of domestic demand (D) and supply (S). The increase in input costs created by the introduction of domestic energy or environmental taxes causes the domestic supply curve to shift inward from $S$ to $S^{*}$. For the exportable good this does not change world prices but causes in inward shift in the quantity supplied from A* to B*. 


\section{Appendix 2}

This appendix provides details of current environmental taxes in the UK. In the UK, there is no single definition of environmental taxation. Based on the primary intention behind the introduction of an environmental the government is developing a workable definition whereas the Office of National Statistics (ONS, 2011) definition focussed more on the effect of a particular tax. ONS defines an environmental tax as

"An environmental tax is defined as a tax whose base is a physical unit such as a litre of petrol, or a proxy for it, for instance a passenger flight, that has a proven specific negative impact on the environment. By convention, in addition to pollution related taxes, all energy and transport taxes are classified as environmental taxes"

This definition has been agreed by international experts and adopted by the Statistical Office of the European Communities (Eurostat) and Organization for Economic Co-operation and Development (OECD). It enables analysis to be based on the effects of taxes rather than the aims behind their introduction, i.e. the aim of a tax for raising government revenue rather than reducing environmental degradation does not preclude it from being defined as an environmental tax (ONS, 2011).

UK environmental taxes are classified into three groups - energy, transport, resource and pollution for statistical purposes. The taxes included in each group are:

- $\quad$ Energy taxes - fossil fuel levy, climate change levy, duty on hydrocarbon oils, renewable energy obligations. The effect of these duties are further increased by charging VAT on them

- $\quad$ Transport taxes: - air passenger duty, vehicle excise duty(VED)

- $\quad$ Pollution taxes - landfill tax

- $\quad$ Resource taxes - aggregates levy

Details of receipts for those taxes included in our analysis are given below:

Receipts from energy and other environmental taxes ( $f$ million):

$20042005 \quad 2006 \quad 2007$

Hydrocarbon oils duty

Climate change levy

Aggregates levy

Landfill tax

$23412.0 \quad 23347.0 \quad 23447.0$

775.3

733.3

334.0

329.0

659.0
720.2

319.0

783.0
$2007 \quad 2008$

Source: HMRC statistics. 